\title{
Gender, Work and Vulnerability in African Horticulture
}

\section{Stephanie Barrientos, Andrienetta Kritzinger, Maggie Opondo and Sally Smith}

\section{Introduction}

Until recently, supplying vegetables, fruit and flowers to supermarkets was seen as a niche area of African export production, likely to involve only a small number of producers. However, sourcing from Africa by European supermarkets has expanded rapidly over the past two decades. In the last ten years there has also been an expansion in supermarket retailing within Africa itself, led by South Africa but now extending into East African countries like Kenya and Tanzania (Weatherspoon and Reardon 2003). ${ }^{1}$ This replicates a global trend towards multiple retailing emanating from the north, also spreading into Latin America and parts of Asia (Reardon and Berdegué 2002). Sourcing by supermarkets, whether in Europe or Africa, will potentially have a profound effect on agricultural production and employment in Africa. European supermarkets prefer to source from larger commercial farms or producer groups that are able to supply consistently high-quality products on a tight but flexible schedule, and in sufficient volumes to fill their shelves (Dolan and Humphrey 2004).

If the same trend is replicated by African supermarkets, this could pose a significant challenge to smallholders and commercial farmers that have traditionally supplied open domestic markets. But demand from supermarkets has led to an expansion of paid work in commercial horticulture. This labour force includes a significant proportion of women, often drawn from the households of male permanent agricultural workers or from smallholder households. In sectors such as horticulture and floriculture this female employment is often temporary, low-paid, informal and insecure. Insecure workers are highly vulnerable to poverty, which is compounded in the case of women who juggle their reproductive role with that of wage earner.
This article draws on research on female labour in horticultural production for UK supermarkets. ${ }^{2}$ It examines the effect of supermarket retailing on employment, and the gender implications for temporary and contract workers, with particular reference to South Africa and Kenya. The article also asks how the vulnerability of such workers could be addressed, and whether the effect of supermarket retailing on workers could be harnessed in a more positive way.

\section{Changing markets}

Export horticulture expanded in many African countries during the 1990s. By 2000, for example, horticulture accounted for 22 per cent of agricultural exports from Kenya, generating US $\$ 118 m$. In 1999 , fruit accounted for 30 per cent of South African agricultural exports, when deciduous exports alone stood at US\$700m. Much of the expansion in sales has initially been to European supermarkets. The shift towards year-round sales of fresh produce, including more exotic ranges of fruit, vegetables and flowers, has stimulated a market for African horticultural products. Initially this market was seen as a niche for high-income consumers in the north. But in several European countries supermarkets now capture an expanding share of grocery sales, which has now reached over 80 per cent in the UK. This trend is being replicated in other continents and more recently in some African countries. In South Africa supermarkets now account for 50-60 per cent of all food retailing, whereas in Kenya supermarkets have grown rapidly to capture over 20 per cent of urban food retailing (Neven and Reardon 2004).

Supermarket food chains operate differently to traditional markets. Rather than being supply or producer driven in line with seasonal availability,

IDS Bulletin Vol 36 No 2 June 2005 @ Institute of Development Studies 
Table 1: Estimated Employment in Export Horticulture in South Africa, Kenya and Zambia

\begin{tabular}{|c|c|c|c|c|}
\hline & & Total employment & Temporary (\%) & Female (\%) \\
\hline \multicolumn{2}{|c|}{$\begin{array}{l}\text { Kenyan flowers } \\
\text { South African deciduous fruit }\end{array}$} & $40,000-70,000$ & $\begin{array}{l}65 \\
283,000\end{array}$ & $\begin{array}{l}75 \\
65-7553\end{array}$ \\
\hline \multirow[t]{2}{*}{ Zambian horticulture } & Veg & 7500 & 77 & 56 \\
\hline & Flowers & 2500 & 32 & 35 \\
\hline
\end{tabular}

Sources: de Klerk n.d., Kritzinger and Vorster (1995 and 1996); NZTT (2003); Blowfield et al. (1998) and KFC (2002) cited in Smith et al. (2004).

Note: The employment figures for South Africa may now be lower following a period of retrenchment.

supermarkets (especially in Europe) typically exert high levels of buyer-led control over their value chains in order to meet consumer demands and maximise their market share. This includes setting stringent specifications and standards (Dolan and Humphrey 2004). While supply is normally preprogrammed up to nine months in advance, suppliers also have to meet any fluctuations in demand at very short notice. In horticulture, price is rarely fixed in advance, and supermarket buyers have taken advantage of falling market prices to extract reduced prices from their suppliers (Barrientos and Kritzinger 2004). Meanwhile, suppliers are asked to comply with an increasing number of codes relating to food safety, protection of the environment, safe use of chemicals, and good labour practices, all of which add to their costs (Smith et al. 2004).

Within Africa, the pattern of sourcing by supermarkets depends in part on the local production context. In South Africa, farming is characterised by medium-sized commercial farms that were consolidated with the expulsion of coloured and black African landowners under the apartheid era. Within the fruit sector, most farms aim to sell their Class 1 fruit through dedicated exporters or to high-value domestic supermarkets. Lower class fruit goes to processing or traditional domestic markets. Total employment in the sector was estimated at 283,000 in 1996, but since then there has been a shift from on-farm labour to the use of off-farm seasonal and contract labour. In Kenya, large commercial farms dominate exports, drawing in produce from smallholders. Smallholder production is the main source of vegetables, fruits and flowers for domestic markets and local supermarkets. Horticultural production and its backward and forward linkages currently provides employment for an estimated two million people of whom 200,000 are smallholders. Smallholders produced over 95 per cent of total national production and accounted for about 55 per cent of the total export volume in 2001, having declined from 60 per cent in 2000 (Fintrac/HDC 2004).

Weatherspoon and Reardon (2003) predict that direct procurement by local supermarkets will increase rapidly, and with that will come the same exacting standards as for export markets. ${ }^{3}$ In South Africa this could lead to a concentration of sourcing from the larger and more efficient farms. This facilitates direct monitoring of quality, environmental and social standards, and guarantees adequate volumes. In Kenya this could contribute to the challenges which already threaten to phase out smallholders from the domestic supply chain. ${ }^{4}$ Packing and preparation of fresh produce and flowers requires investment in packhouses and food processing plants, and the cool chain involves high capital costs. Smaller producers typically lack access to sufficient capital or credit to meet these requirements, except where they are organised into producer groups, or are linked to a lead supplier/packer (Dolan and Humphrey 2000). Rather than offering smallholders new market opportunities, many supermarkets are undergoing a process of concentrating their sourcing from commercial farms. While this may have a negative impact on small producers, it could generate new employment opportunities including for displaced producers. ${ }^{5}$

\section{Gender and employment}

Commercial farms and packhouses require a significant waged labour force, particularly where 
packing is involved. Despite modernisation of production, horticulture remains a labour-intensive sector, with labour accounting for 50-60 per cent of farm costs. A significant amount of this employment is temporary and female (Table 1). Gender segregation is common, with men occupying the more senior permanent positions and women concentrated in more insecure temporary positions. This includes fixed-term contracts of between one and six months, and casual day work. In countries such as South Africa, fluctuating demand for labour is also met through the use of third party "contractors", who take on the role of employer and move gangs of workers around between different farms (Kritzinger and Barrientos 2004; du Toit and Ally 2001).

Seasonality of production has always been an important factor in determining demand for agricultural labour. However, as production techniques have advanced, in many crops the seasons have been extended and demand for labour can last for long periods - even up to 12 months a year in the case of flowers or for some contract workers who move between farms and activities. Despite the fact that many workers are employed most of the year and repeatedly return to the same employer, they are still classed as "temporary". They do not benefit from the security and legislated entitlements of permanent employment, and often do not even receive those benefits to which they are legally entitled as temporary workers. This is particularly true of the large number who are employed "informally", i.e. without formal contracts of employment. These informal workers, many of whom are women, lack even the most basic legal protection or employment rights.

Flexibility of employment is another key element behind the large temporary labour force found in commercial horticulture - and women are often seen as more "flexible" than male workers. Intense competition and falling prices have created pressure on growers and dedicated packhouses to minimise labour costs. Flexible employment allows them to do this by minimising the labour they retain and varying the length of the working day. The need for flexibility is also driven by supermarket sourcing patterns. Growers and packers have to meet tight supermarket schedules, and often have to supply additional products at short notice for a supermarket promotion, or if consumer demand changes. ${ }^{6}$ The consequences were highlighted in a recent Oxfam report, which examined the links between poor labour conditions and supermarket purchasing practices (Oxfam 2004).

High levels of female employment relate partly to the perceived "skill" and "dexterity" of women in handling delicate produce, which is key to maintaining the quality demanded by supermarkets. But these skills have been largely socially instilled as girls are prepared for a domestic role within society. Despite undertaking tasks that add significant value, women can be employed on low wages with little training. They are seen as docile, compliant and accepting of poor employment conditions, often because they are ill-informed about their rights. Given that trends in the supermarket sector appear to be similar across different regions, the demand for cheap, flexible, female waged labour could continue to grow. This raises questions about the implications of this type of employment for poverty alleviation.

\section{Work and vulnerability to poverty: horticulture workers in Kenya and South Africa}

The extent to which commercial horticulture provides a route out of poverty varies between countries and type of worker. In Kenya temporary women workers are ensnared in a poverty trap. For example, temporary female workers in the cutflower industry work long hours for low pay, and rarely have access to benefits such as sick pay, medical care and maternity leave (Dolan et al. 2003). Poverty is compounded by their productive and reproductive roles. Benefits (such as maternity leave, childcare provision and transport) which enable women to balance unpaid caring work with paid work are often not extended to temporary workers. The vulnerability of women workers is made worse by lack of employment security and involuntary periods out of work.

In South African horticulture there is a hierarchy of employment. Better incomes and employment conditions are generally found at higher levels of the hierarchy, among workers in dedicated packhouses. Workers at the lower end (especially non-permanent farmworkers) experience low wages and increasingly insecure employment. Contract workers and migrant workers are at the bottom of the hierarchy. They experience the lowest incomes, rarely receive any benefits, and have high levels of insecurity and vulnerability to poverty (Kritzinger and Barrientos 
2004). These workers often live in squalid conditions in farm quarters or rural townships.

A narrow focus on income and consumption can easily underestimate the extent and depth of poverty among horticultural workers. Household size is another important factor, as is duration of periods of employment and unemployment. In addition, the less employment benefits or legal protection a worker has, the greater their vulnerability to poverty. Lack of benefits is most common amongst temporary and contract workers in African horticulture, whether production is for export or domestic markets. Seasonal, migrant and contract workers who are removed from their social networks, or live in peri-urban shanty towns, lack basic forms of social protection that traditionally constitute an important form of support.

Vulnerability also has a gender dimension. Women temporary and contract workers are likely to work for shorter periods in the year than men, and in both Kenya and South Africa often earn lower wages for comparable work than male colleagues (Smith et al. 2004). ${ }^{7}$ Women are more likely to be juggling paid work with childcare and family responsibilities. They not only carry the risks arising from insecure and often informal work, they also carry the risks of illness, accident and old age among family dependents. If a child or elderly relative is sick, and a temporary or contract worker has to take time off, she may not only lose income but possibly her job. The HIV/AIDS pandemic coupled with cost-sharing in the health service has invariably increased the burden of health care on women. ${ }^{8}$ Women who become pregnant also risk losing their jobs if they have no formal right to maternity leave, and often hide their pregnancy as a result (Smith et al. 2004). Thus for women workers caught between productive and reproductive roles, their exposure to risk and vulnerability is magnified.

\section{Addressing vulnerability}

Legislation covering female temporary workers in agriculture is often weak, particularly with regard to laws designed to protect women workers from discrimination and guarantee them equal opportunities in the workplace. In 1997 the Kenyan constitution was amended to include a specific prohibition of discrimination on the basis of gender (IBLF 2002). The government has yet to enact the statutes that recognise equal pay for equal work. Kenyan legislation is silent on the rights of temporary workers, since it is based on the notion that employment is full-time and permanent (Dolan et al. 2003).

In South Africa, although labour legislation has formally been extended to all categories of farm employment, contract workers have virtually no access to benefits and protection provided by legislation. Contractors often fail to formally register as employers with the Department of Labour. Contract work involves different workplaces and high levels of mobility, which militates against the successful implementation and monitoring of legislation, and constrains the collective organisation of these workers and their ability to claim their rights.

Supermarket retailing has provided a potential route for addressing the vulnerability of workers in commercial horticulture. Many European supermarkets now have codes of labour practice, which set out minimum rights for workers in relation to issues such as health and safety, pay and hours of work, and which suppliers have to uphold. Better codes of practice are based on Core International Labour Organization Conventions which cover discrimination and freedom of association, as well as child labour and forced labour. ${ }^{9}$ However, while codes may benefit permanent workers, they often fail to reach temporary, migrant and contract workers, and are weak at addressing gender issues (Smith et al. 2004). Some African supermarkets are also pursuing policies around corporate social responsibility, which could extend to include labour issues. In both South Africa and Kenya, local multistakeholder initiatives have been set up to implement and monitor codes of labour practice in the wine and horticulture sectors. ${ }^{10}$

A related response to support local producers and workers has been the growth of Fairtrade products sourced from Africa. These now include coffee, tea, flowers, fruit, honey and a range of other products. Fairtrade labelled goods guarantee the producers a minimum price and offer a 15 per cent social premium which is returned to producers for social projects (schools, clinics, sports facilities). Fairtrade covers small producers and also larger commercial farms where social principles are met. Where workers are employed, Fairtrade also has a code of labour practice (as above) aimed at ensuring minimum employment standards. The sale of Fairtrade labelled goods in Europe has grown rapidly in recent years, and many African producers are keen to become Fairtrade accredited (Smith and 
Barrientos 2005). ${ }^{11}$ The sale of Fairtrade goods could expand in Africa itself. But fair trade is always likely to remain a niche, the benefits of which only reach a small proportion of workers employed in the expanding African horticulture sector.

For the majority of producers, it is argued that supermarket purchasing practices (insecurity of contracts, "just in time" ordering and lowering of prices) are helping to reinforce the risk and vulnerability faced by an insecure workforce (Oxfam 2004). In South Africa a small non-governmental organisation (NGO) which is linked to Oxfam and called Women on Farms, is campaigning against the effects of UK supermarket purchasing practices on workers. In Kenya, a women's NGO (Kenya Women Workers Organisation) took up issues around women flower workers engaged in production for UK supermarkets. International campaigns linking trade unions with NGOs in the south and north aimed at ensuring that supermarket purchasing practices do not undermine suppliers' ability to offer better and more secure employment are growing. More socially responsible commercial relationships need to be complemented by public policy that supports producers and workers in a changing retail environment increasingly dominated by supermarkets.

\section{Notes}

1. The South African supermarket chain Shoprite has 119 outlets in 16 African countries, as well as India.

2. Department for International Development Projects: Globalisation and Poverty Programme (2000-3); Ethical Trade in African Horticulture (2002-4). The views expressed in this article are the authors' alone.

3. The challenges for smallholders of expanding supermarket retailing were the focus in 2004 of an E-Conference as part of the Re-governing Markets programme - see www.regoverningmarkets.org. See also Vorley (2004).

4. These include poor market facilities, high fluctuations in supply and price, lack of marketing organisations representing growers, inconsistency in the quality of products, and lack of standards (Fintrac/HDC 2004).

5. McCulloch and Ota (2002) have argued that wage employment can have a similar effect on poverty reduction as smallholder production.

\section{Conclusion}

Commercial production for supermarkets, which initially serviced European supermarkets alone, looks set to expand in Africa as supermarkets become more prevalent within the region itself. Much of the employment generated by commercial horticulture for supermarkets is female, insecure and informal. Social codes of individual supermarkets are likely to be limited in their ability to address the wider poverty and gender issues in a commercial environment of shortening lead times and falling prices. In a rapidly changing commercial environment, increasingly dominated by large supermarkets and similar retailers, it is important that government policy and private initiatives join up to ensure fairer trade, and provide protection for workers. Policy which has often focused on small producers also needs to be alert to the needs of insecure and flexible workers and embody a strong gender focus. Developing such a strategy is a major challenge in the context of deregulated African economies, but only through this is the trend to more waged labour in commercial agriculture likely to contribute to poverty alleviation and more sustainable development.

6. For example, UK demand for lemons goes up substantially during sunny periods as people drink more gin and tonics (Capespan, pers. comm. 2004).

7. One exception to this can be in packhouses, where women are able to earn higher wages, largely through piecework.

8. Under neoliberal reforms several African governments have significantly reduced their health budgets, part of which cost must be borne by individuals.

9. See for example the UK Ethical Trading Initiative (ETI), www.ethicaltrade.org (accessed April 2005).

10. Wine Industry Ethical Trading Initiative (WIETA) in South Africa and the Horticulture Ethical Business Initiative (HEBI) in Kenya.

11. For example the sale of Fairtrade goods in the UK increased by 50 per cent in 2003-4, standing at $£ 92 \mathrm{~m}$ (www.fairtrade.org.uk, accessed April 2005). 


\section{References}

Barrientos, S. and Kritzinger, A., 2004, 'Squaring the circle: global production and the informalization of work in South African fruit exports', Journal of International Development 16: 81-92

Dolan, C. and Humphrey, J., 2004, 'Changing governance patterns in the trade in fresh vegetables between Africa and the United Kingdom', Environment and Planning A, Vol 36 No 3: 491-509

Dolan, C. and Humphrey, J., 2000, 'Governance and trade in fresh vegetables: the impact of UK supermarkets on the African horticulture industry', Journal of Development Studies, Vol 37 No 2: 147-76

Dolan, C., Opondo, M. and Smith, S., 2003, 'Gender, rights, and participation in the Kenya cut flower industry', NRI Report No 2768, Chatham Maritime: Natural Resources Institute

du Toit, A. and Ally, F., 2001, 'The Externalisation and Casualisation of Farm Labour in Western Cape Horticulture', report compiled by the Programme for Land and Agrarian Studies, School of Government, University of the Western Cape for the Centre for Rural Legal Studies, Stellenbosch

Fintrac/HDC (Horticulture Development Centre), 2004, Market Study - Domestic Market for Fruits and Vegetables, Nairobi: Fintrac/HDC

IBLF (International Business Leaders Forum), 2002, 'Violence Against Women in the Workplace in Kenya: Assessment of Workplace Sexual Harassment in the Commercial Agriculture and Textile Manufacturing Sectors in Kenya', www.laborrights.org/projects/women/kenya report.pdf
Kritzinger, A. and Barrientos, S., 2004, 'Global production and flexible employment in South African horticulture: experiences of contract workers in fruit exports', Sociologia Ruralis, Vol 44 No 1: 17-39

McCulloch, N. and Ota, M., 2002, 'Export horticulture and poverty in Kenya', IDS Working Paper 174, Brighton: Institute of Development Studies

Neven, D. and Reardon, T., 2004, 'The rise of Kenyan supermarkets and evolution of their horticulture product procurement systems', Development Policy Review, Vol 22 No 6: 669-99

Oxfam, 2004, Trading Away our Rights: Women Working in Global Supply Chains, Oxford: Oxfam International

Reardon, T. and Berdegué, J.A., 2002, 'The rapid rise of supermarkets in Latin America: challenges and opportunities for development', Development Policy Review, Vol 20 No 4: 317-34

Smith, S. and Barrientos, S., 2005, 'Trade and ethical trade: are there moves towards convergence?', Sustainable Development, Vol 13 No 3

Smith, S., Auret, D., Barrientos, S., Dolan, C., Kleinbooi, K., Njobvu, C., Opondo, M. and Tallontire, A., 2004, 'Ethical trade in African horticulture: gender, rights and participation', IDS Working Paper 223, Brighton: Institute of Development Studies

Vorley, B., 2004, Food Inc: Corporate Concentration from Farm to Consumer, London: UK Food Group

Weatherspoon, D. and Reardon, T., 2003, 'The rise of supermarkets in Africa: implications for agrifood systems and the rural poor', Development Policy Review, Vol 21 No 3: 333-55 